\title{
Timing of clockwise rotation of Southwest Japan: constraints from new middle Miocene paleomagnetic results
}

\author{
Hiroyuki Hoshi ${ }^{1 *}$, Daiki Kato ${ }^{1}$, Yoshikazu Ando ${ }^{1}$ and Kazuo Nakashima ${ }^{2}$
}

\begin{abstract}
Southwest Japan rotated clockwise during the late stage of the opening of the Japan Sea, although the exact timing of the rotation is controversial. A recent biostratigraphic study has revealed that the Miocene Oidawara Formation in eastern Southwest Japan was deposited just before $15 \mathrm{Ma}$; consequently, its paleomagnetic direction may help constrain the timing of rotation. For this purpose, we collected fine felsic tuffs and siltstones at 71 stratigraphic sites (horizons) in the Oidawara Formation. An analysis of alternating field and thermal demagnetization results yielded characteristic remanent magnetization (ChRM) directions for 177 samples. Approximately $80 \%$ (142) of the samples exhibit reverse polarity ChRM directions that are thought to be paleofield directions of reverse polarity Chron C5Br. Normal polarity ChRM directions in 35 samples include primary paleofield records as well as records of secondary magnetization. The data suggest that a short normal polarity interval (microchron or cryptochron) at 15.8 $\mathrm{Ma}$ is present within the dominantly reverse polarity interval of Chron C5Br. Reliable site-mean directions for 19 sites yield a tilt-corrected formation-mean direction of $D=10.5^{\circ}, I=41.1^{\circ}, a_{95}=7.0^{\circ}$, and $k=23.9$, indicating virtually no rotation with respect to a reference paleomagnetic direction for the Asian continent. A rotation versus age plot for Southwest Japan indicates that the clockwise rotation started after $17.5 \mathrm{Ma}$ and ceased largely before 15.8 Ma, yielding a rotation rate of $\sim 23^{\circ} / \mathrm{Myr}$.
\end{abstract}

Keywords: Magnetostratigraphy; Miocene; Mizunami Group; Oidawara Formation; Paleomagnetism; Rock magnetism; Southwest Japan; Tectonic rotation

\section{Background}

The eastern Asian and western Pacific margins, including the Japanese islands, are the areas where relative plate motions caused several remarkable tectonic events during the Cenozoic, such as back-arc opening (e.g., Martin 2011; Sasaki et al. 2014), arc-arc collision (e.g., Arai and Iwasaki 2014), and severe intra-arc crustal deformation (e.g., Cho and Kuwahara 2013; Itoh et al. 2014). The clockwise rotation of Southwest Japan (Otofuji and Matsuda 1983; Torii 1983) is a conspicuous example of such tectonic events. The general consensus among researchers is that this rotation, along with the counterclockwise rotation of Northeast Japan (Otofuji et al. 1985c, 1994; Hoshi and Takahashi 1999), was directly

\footnotetext{
* Correspondence: hoshi@auecc.aichi-edu.ac.jp

${ }^{1}$ Department of Earth Sciences, Aichi University of Education, Kariya, Aichi 448-8542, Japan

Full list of author information is available at the end of the article
}

linked to the opening of the Japan Sea, which is a back-arc basin located behind rotating slivers of both the Southwest and Northeast Japan arcs (Fig. 1). The rifting of the two arc slivers from the Asian continent began in the Oligocene (or possibly late Eocene) and ended at $\sim 15$ $\mathrm{Ma}$, as determined by on-land geological studies in Japan and South Korea (Yoon 1997; Kano et al. 2007), as well as Ocean Drilling Program (ODP) results from the Japan Sea (Tamaki et al. 1992). Numerous paleomagnetic studies have revealed that both arcs rotated in the early to middle Miocene (Hoshi et al. 2013, and references therein); that is, rotation occurred during the late stage of the opening of the Japan Sea. However, for reasons noted below, we consider that the exact timing of the rotation is still uncertain.

The classic and well-known model for the clockwise rotation of Southwest Japan, proposed by Otofuji et al. (1985a, b), suggests that Southwest Japan rotated rapidly 


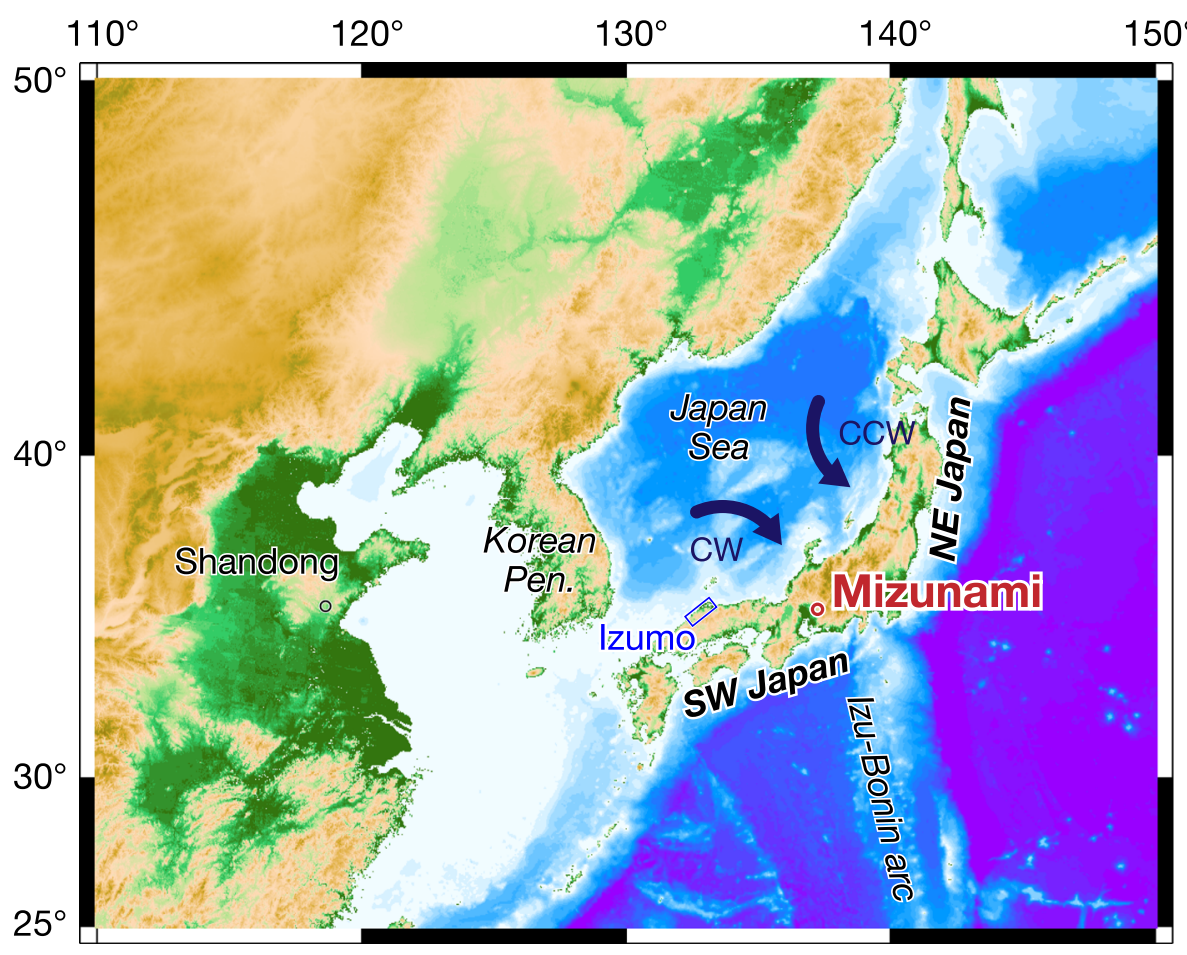

Fig. 1 Map of Japan and surrounding regions, showing the location of the study area (Mizunami). The location of the Izumo area (Sawada et al. 2013) is also shown. Southwest (SW) Japan and Northeast (NE) Japan rotated clockwise (CW) and counterclockwise (CCW), respectively, during the late stage of opening of the Japan Sea (see text). Base map was generated using 'Map-It' (http://woodshole.er.usgs.gov/mapit/)

at ca. 15 Ma. This model, hereafter called the 15-Ma rapid rotation model, is supported by several studies based on data from volcanic rocks (Otofuji et al. 1991; Shimada et al. 2001). However, this model has been questioned, given the results of a number of paleomagnetic and geochronological studies (e.g., Nakajima et al. 1990; Jolivet et al. 1995) that cite an absence or lack of data for the rotation of rocks dating from ca. $15 \mathrm{Ma}$ in some areas of Southwest Japan (Hoshi and Sano 2013; Sawada et al. 2013; and references therein), thus leading to an alternative view that clockwise rotation occurred before (not at) 15 Ma (e.g., Nakajima et al. 1990; Hoshi et al. 2000b). However, the majority of such data are from volcanic rocks which have been radiometrically dated by conventional $\mathrm{K}-\mathrm{Ar}$ or fission track methods, which are subject to significant uncertainties. Therefore, determination of the paleomagnetic direction of accurately dated rock units is critical for testing the 15-Ma rapid rotation model.

Here, we present new paleomagnetic results for finegrained sedimentary rocks of the Oidawara Formation, the uppermost lithological unit of the lower to middle Miocene Mizunami Group in eastern Southwest Japan (Fig. 1). The paleomagnetic direction of this formation is expected to provide a reliable and robust test of the 15-Ma rapid rotation model, because its age, which is biostratigraphically well constrained, indicates that it was deposited immediately prior to $15 \mathrm{Ma}$ (Kawamura et al.
2011). Interestingly, previous paleomagnetic data for this formation reported by Hayashida (1986) appear to indicate a paleomagnetic direction that is deflected only slightly eastward relative to present-day north. Hayashida (1986) suggested that the formation was deposited during the rotation of Southwest Japan. However, the data consist of only two site-mean directions, which are insufficient to determine the amount or rate of rotation. The Oidawara Formation attains a maximum thickness of over $80 \mathrm{~m}$, which should be sufficient to give a reliable timeaveraged paleofield direction in which the paleosecular variation can be averaged reliably, based on paleomagnetic sampling of numerous stratigraphic horizons.

\section{Geological setting}

The Mizunami Group consists of clastic sedimentary rocks (conglomerate, sandstone, siltstone, and tuff) and unconformably overlies Late Cretaceous igneous rocks (Itoigawa 1974, 1980; Sasao 2013). The group has a maximum thickness of $\sim 600 \mathrm{~m}$ and is divided into five formations (in ascending order): the Toki Lignite-Bearing, Hongo, Akeyo, Shukunohora, and Oidawara formations (Fig. 2). The depositional setting of the lower two units is non-marine and that of the upper three is largely shallow marine. The Oidawara Formation unconformably overlies the Shukunohora Formation, which in turn unconformably overlies the Akeyo Formation. Strata of the 


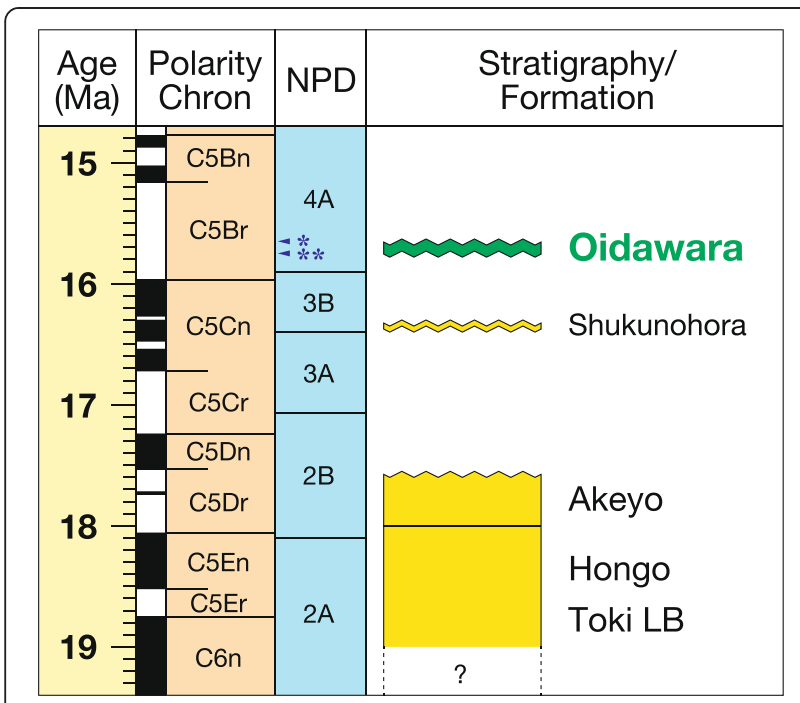

Fig. 2 Chronostratigraphy of the Mizunami Group, modified from Ujihara et al. (1999). The geomagnetic polarity time scale is after Ogg (2012). The Neogene North Pacific diatom zones (NPD; after Yanagisawa and Akiba 1998) were adjusted to the Ogg (2012) time scale by the authors, following the magneto-biostratigraphic correlation developed by Watanabe and Yanagisawa (2005). Two important biohorizons within NPD4A are indicated: single asterisk first occurrence of Actinocyclus ingens f. nodus ( 15.7 Ma), double asterisks last occurrence of Denticulopsis praelauta ( 15.8 Ma). Toki LB Toki Lignite-Bearing Formation

Mizunami Group are essentially flat-lying, with maximum dips of only $\sim 20^{\circ}$.

The Oidawara Formation consists almost entirely of greenish gray siltstone, with a basal conglomerate bed (1-2 m thick); the formation is $80-90 \mathrm{~m}$ thick at Shuku, where we obtained samples for this study (Figs. 3 and 4). A fine felsic tuff $(\sim 5 \mathrm{~cm}$ thick $)$ is present in the middle of the formation and is a key marker bed for the correlation of lithologic sections. At the Shuku locality, strata dip gently southward and form a homoclinal succession. Detailed geological mapping of the tuff bed indicates that bedding has a strike/dip of $N 72^{\circ} \mathrm{E} / 3^{\circ} \mathrm{S}$, which we used in our tilt corrections of the paleomagnetic directions.

Radiometric, magnetostratigraphic, and micropaleontological data constrain the depositional age of the Mizunami Group. Zircon fission track results suggest that the group was deposited in the early to middle Miocene (Kobayashi 1989; Sasao et al. 2006, 2011), although no data have been reported for the Oidawara Formation. Paleomagnetic polarity and marine microfossil data, including biostratigraphic data for planktonic foraminifera, radiolaria, and diatoms, constrain the age of the shallow marine sediments within the Mizunami Group (Kawamura et al. 2011, and references therein). Ujihara et al. (1999) suggested that the Akeyo Formation lies within Chron C5Dr (18.056-17.533 Ma; Ogg 2012), based on the presence of reverse paleomagnetic directions (Hayashida 1986; Hiroki and Matsumoto 1999) and fossil diatoms indicative of diatom zone NPD 2B (Gladenkov 1998); they also suggested that the age of the Shukunohora Formation is ca. 16.5-16.0 Ma. Kawamura et al. (2011) showed that the Oidawara Formation was deposited during a short period ( 0.1 Myr or less) between the last occurrence of Denticulopsis praelauta $(\sim 15.8 \mathrm{Ma})$ and the first occurrence of Actinocyclus ingens f. nodus ( 15.7 Ma), both within NPD 4A (Fig. 2). An average sedimentation rate of $\sim 90 \mathrm{~cm} / \mathrm{kyr}$ or higher is thus estimated for the Oidawara Formation. Two reverse polarity directions reported by Hayashida (1986) are compatible with the results of diatom biostratigraphy, which suggest that deposition of the formation occurred during Chron C5Br (15.974-15.160 Ma), based on the diatom biochronology of Yanagisawa and Akiba (1998) and Watanabe and Yanagisawa (2005).

\section{Methods}

To investigate stratigraphic/temporal variations in paleomagnetic directions, we collected sedimentary rock samples at 71 stratigraphic sites (horizons) in two stratigraphic sections (eastern and western) in the Oidawara Formation, located near Shuku (Figs. 3 and 4). Samples were collected from 28 sites in the eastern section (E1-E28) and 43 sites in the western section (W1-W43). The two sections can be confidently correlated using the key marker (tuff) bed described above. The samples consist mostly of siltstone, with two fine tuff sites representing the marker tuff bed (E12 and W13). At each site, one to three magnetically oriented cores $(25 \mathrm{~mm}$ in diameter) were collected using a battery-powered portable drill. Care was taken to obtain long $(\geq 10 \mathrm{~cm})$ cores to improve the precision of orientation measurements. Each core was cut in the laboratory into one to four 22-mm-long cylindrical samples for magnetic measurements.

Measurements and demagnetization of natural remanent magnetization (NRM) were carried out in the Paleomagnetic Laboratory at the Center for Advanced Marine Core Research, Kochi University (referred to as the Kochi Core Center), Japan. Remanent magnetization was measured with a $2 \mathrm{G}-760 \mathrm{R}$ pass-through superconducting rock magnetometer (SRM) housed in a magnetically shielded room. All samples were demagnetized stepwise: alternating field demagnetization (AFD) was performed to a maximum field of $80 \mathrm{mT}$ using an inline AFD system of the pass-through SRM and thermal demagnetization (ThD) was performed in air to a maximum temperature of $600{ }^{\circ} \mathrm{C}$ using a Natsuhara TDS-1 thermal demagnetizer. During stepwise ThD, thermal alteration of minerals was monitored by measuring the low-field magnetic susceptibility of samples at each demagnetization step (the measurements were performed using a Bartington MS2 meter). Directions of linear components were determined by a principal component analysis 


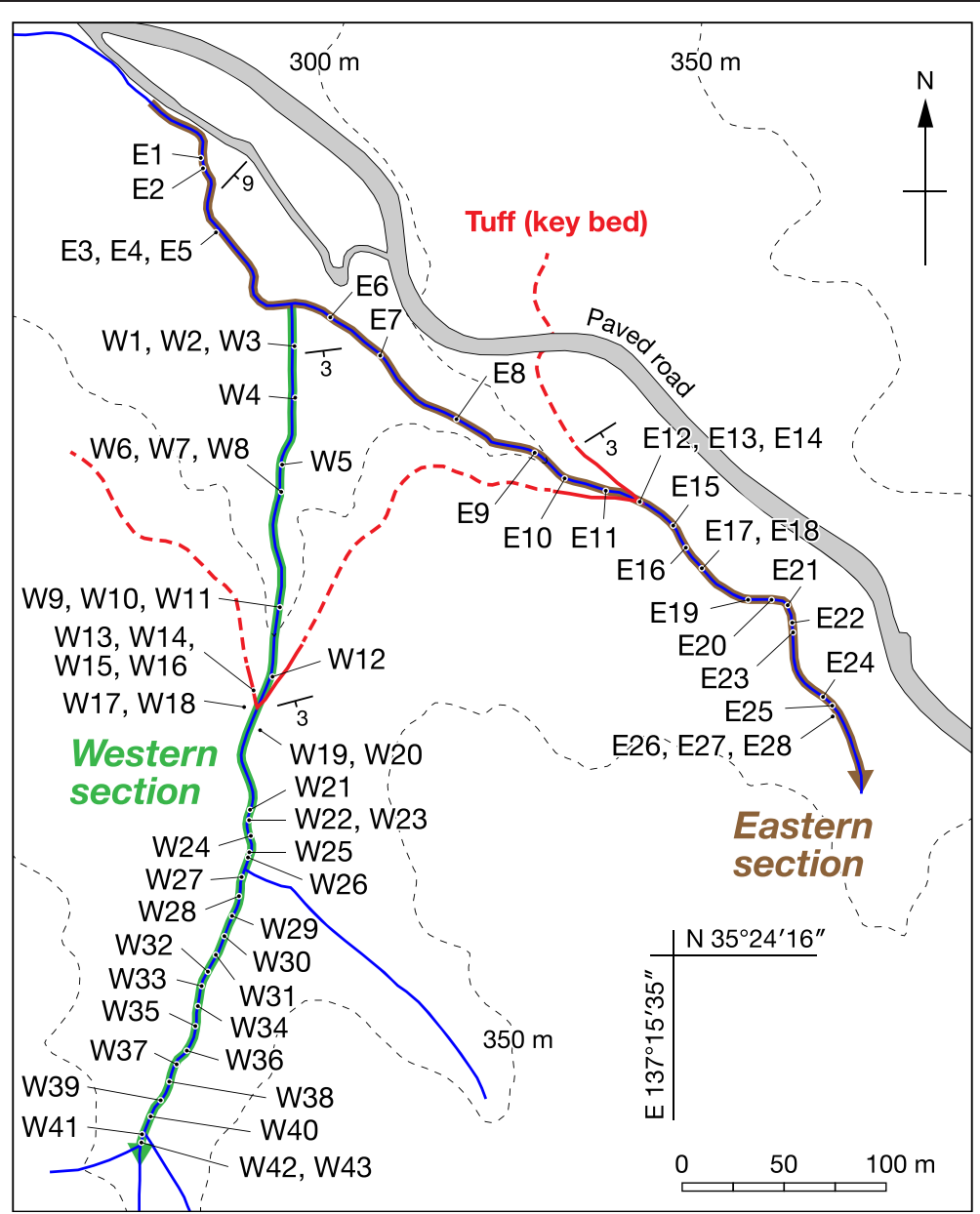

Fig. 3 Map of the Shuku locality, showing locations of paleomagnetic sampling sites in the eastern and western stratigraphic sections of the Oidawara Formation. Arrows on both sections indicate the younging direction. The red line is the surface trace of the fine felsic tuff bed in the middle of the Oidawara Formation; gray dashed lines are topographic contours

(PCA; Kirschvink 1980) of stepwise demagnetization data using the software PuffinPlot ver. 1.02 (Lurcock and Wilson 2012). For the PCA, we performed both free line fitting (FLF) and anchor line fitting (ALF) on more than two vector end points showing a linear trajectory decaying to the origin on an orthogonal projection. Further analyses were undertaken on demagnetization data that yielded an ALF direction with a maximum angular deviation (MAD) of less than $15^{\circ}$; in these analyses, we computed the angular difference between the FLF and ALF directions, and if the angle was $<15^{\circ}$, we defined the ALF direction as the characteristic remanent magnetization (ChRM) direction. If more than two ChRM directions were obtained for a site and formed a moderate to tight cluster, we calculated the site-mean direction and related statistical parameters.

Additional experiments were performed on selected samples to obtain various rock magnetic properties. Following Lowrie (1990), stepwise ThD of three-axis isotheral remanent magnetization (IRM) was carried out after imparting a composite IRM (hard, medium, and soft coercivity components) by sequentially applying steady fields of 3.0, 0.4 , and $0.12 \mathrm{~T}$ along three orthogonal axes using a Magnetic Measurements MMPM-10 pulse magnetizer. The ThD of the IRM was performed using a Schonstedt TSD1 thermal demagnetizer, and the IRM was measured with a Natsuhara ASPIN spinner magnetometer; both instruments were housed in the Paleomagnetic Laboratory at Aichi University of Education, Japan. Hysteresis measurements were conducted with a Princeton Measurements MicroMag 3900 vibrating sample magnetometer (VSM) at the Kochi Core Center. To investigate magnetic mineralogy, we also obtained images and compositional analyses of both bulk sedimentary samples and magnetic separates using a JEOL JXA-8600 electron probe microanalyzer (EPMA) at Yamagata University, Japan.

\section{Results and discussion}

Felsic tuff

The tuff samples consisted of a mixture of fine felsic volcanic ash and silt. All samples displayed a straightforward 


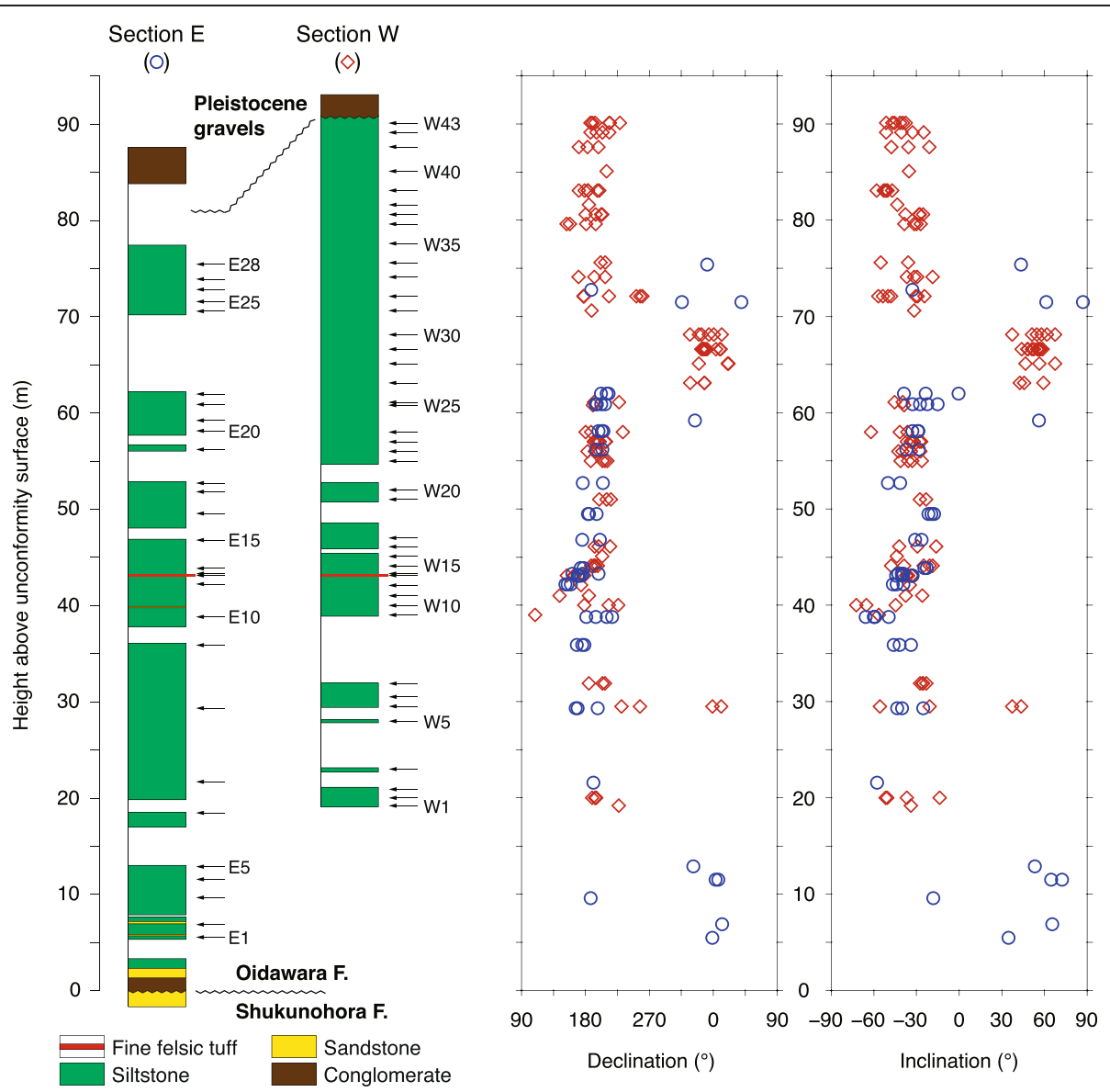

Fig. 4 Declinations and inclinations of sample ChRM directions for the eastern $(E)$ and western $(W$ ) outcrop sections at the Shuku locality. Blue circles and red diamonds represent data for the eastern and western sections, respectively. Arrows on the right side of each lithologic column indicate sampling horizons

behavior during stepwise demagnetization (Fig. 5a-d), yielding reverse ChRM directions that show a directional similarity between samples treated by AFD and ThD. The site-mean directions for the two tuff sites (E12 and W13) were statistically indistinguishable (see Table 1 ), suggesting that the paleomagnetic direction of the tuffs from the two sites were acquired at the same time.

Stepwise ThD of three-axis IRM (Fig. 6a) indicates that magnetite is the main carrier of remanent magnetization in the tuff. The soft, medium, and hard coercivity components were all completely demagnetized at $575{ }^{\circ} \mathrm{C}$. A change in slope in the soft component at $\sim 300{ }^{\circ} \mathrm{C}$ indicates the presence of Ti-rich titanomagnetite $(x \approx 0.4$, where $x$ is the amount of Ti substitution in titanomagnetite) or ferromagnetic iron sulfide (e.g., greigite). During stepwise $\mathrm{ThD}$, the low-field magnetic susceptibility increased at temperatures higher than $350{ }^{\circ} \mathrm{C}$, possibly due to the transformation of ferromagnetic iron sulfide to magnetite. Hysteresis measurements indicate a grainsize distribution within a pseudo-single-domain (PSD) range (red diamonds, Fig. 7). It should be noted that during stepwise ThD of NRM, ChRM directions were determined over a wide temperature range $\left(100-500{ }^{\circ} \mathrm{C}\right)$ and that no significant directional changes were observed at around $300{ }^{\circ} \mathrm{C}$. Therefore, the direction recorded by ferromagnetic iron sulfide, if present, is essentially the same as that of magnetite, and thus, remanent magnetization in ferromagnetic iron sulfide is interpreted as the magnetization direction acquired at or immediately after deposition. The EPMA analyses did not detect any ferromagnetic minerals, probably due to the very small (submicron?) grain size, but they did detect paramagnetic iron-bearing minerals, such as detrital ilmenite and authigenic pyrite.

\section{Siltstone}

Of the 280 siltstone samples analyzed, 169 yielded ChRM directions (Tables 1 and 2). At sites where ChRM components were isolated from NRMs by both demagnetization techniques, the directions revealed by the two techniques were generally in agreement, as shown in Fig. 5e-j. In general, remanent magnetization 


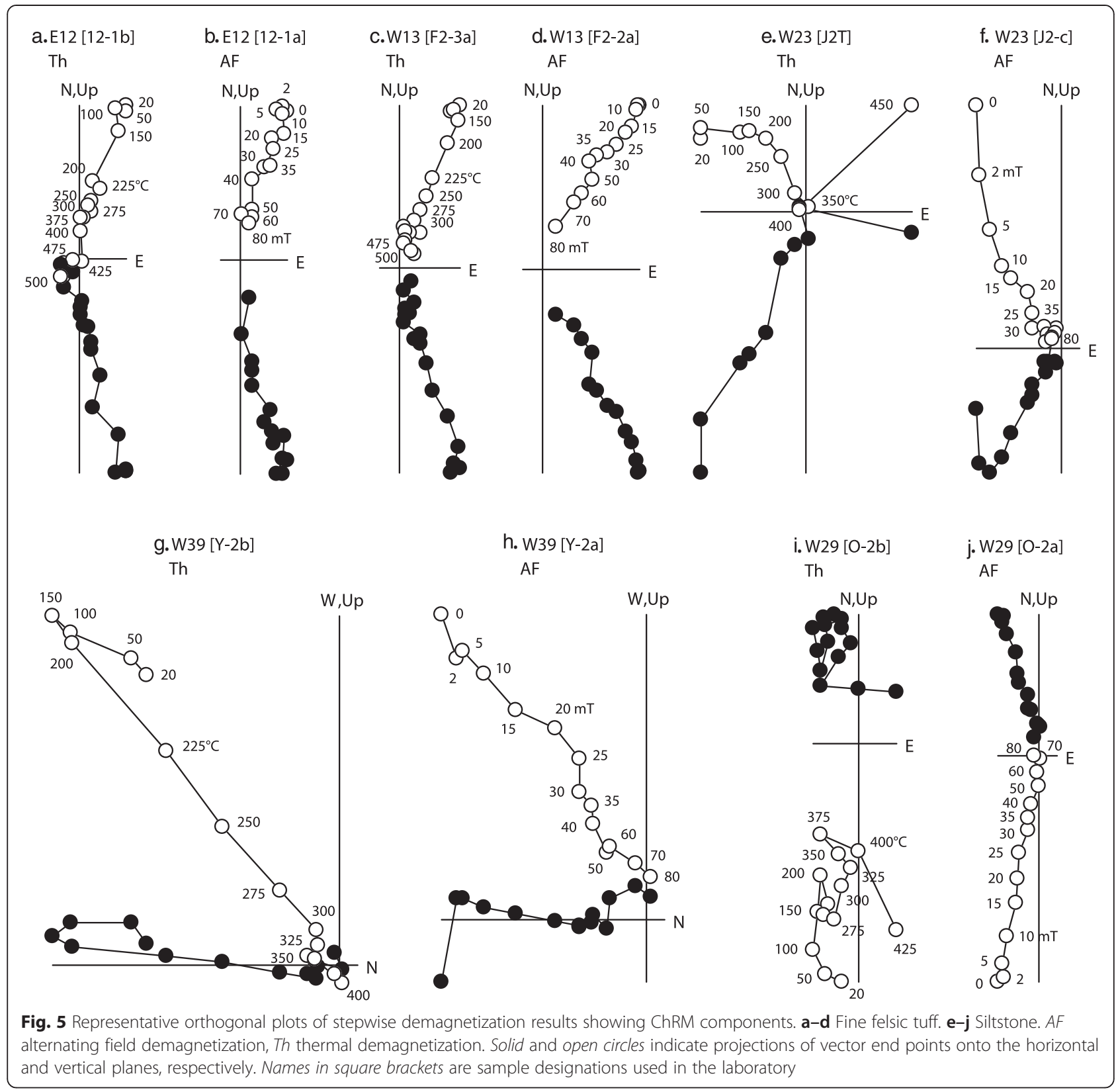

in siltstones was largely demagnetized by $80 \mathrm{mT}$ during stepwise AFD and virtually completely unblocked at $300-350{ }^{\circ} \mathrm{C}$ during stepwise ThD. As in the tuff samples described above, nearly all siltstone samples experienced thermal alteration at temperatures higher than $350{ }^{\circ} \mathrm{C}$, represented by a significant increase in low-field magnetic susceptibility and/or in the intensity of remanent magnetization. Stepwise ThD of three-axis IRM displayed two major unblocking temperatures (Fig. $6 \mathrm{~b}, \mathrm{c}$ ): $\sim 575{ }^{\circ} \mathrm{C}$, undoubtedly indicating magnetite and $250-300{ }^{\circ} \mathrm{C}$, probably indicative of $\mathrm{Ti}$-rich titanomagnetite or ferromagnetic iron sulfide, as in the tuff samples. Hysteresis data plotted within the PSD range and were similar to those from the tuff (Fig. 7). Collectively, these observations suggest that the remanent magnetization is carried mainly by magnetic minerals with an unblocking temperature of $\sim 350{ }^{\circ} \mathrm{C}$, most likely ferromagnetic iron sulfide. As in the case of the fine tuff, EPMA analyses did not detect any ferromagnetic iron sulfide.

\section{Paleomagnetic polarity}

The stratigraphic plots of in situ (geographic) sample ChRM directions for the eastern and western sections are displayed in Fig. 4. Both sections show dominantly southerly declinations (typically $170^{\circ}-210^{\circ}$ ) and negative inclinations (typically $-20^{\circ}$ to $-50^{\circ}$ ), which is 
Table 1 Directions of reverse polarity ChRM components

\begin{tabular}{|c|c|c|c|c|c|c|c|}
\hline Site & $n_{a f} / n_{t h} / n / N$ & $\begin{array}{l}D_{i} \\
\left(^{\circ}\right)\end{array}$ & $\begin{array}{l}I_{i} \\
\left(^{\circ}\right)\end{array}$ & $\begin{array}{l}D_{c} \\
\left({ }^{\circ}\right)\end{array}$ & $\begin{array}{l}I_{c} \\
\left(^{\circ}\right)\end{array}$ & $\begin{array}{l}a_{95} \\
\left(^{\circ}\right)\end{array}$ & k \\
\hline W1 & $1 / 0 / 1 / 1$ & 227.0 & -33.9 & 228.9 & -35.1 & & \\
\hline W2 & $2 / 2 / 4 / 1$ & 193.0 & -38.3 & 194.3 & -40.9 & 20.5 & 21.0 \\
\hline W6 & $1 / 1 / 2 / 1$ & 240.5 & -38.9 & 242.9 & -39.4 & & \\
\hline W8 & $3 / 1 / 4 / 1$ & 200.3 & -25.7 & 201.3 & -28.0 & 10.7 & 74.3 \\
\hline W9 & $1 / 0 / 1 / 1$ & 109.2 & -56.4 & 105.4 & -58.1 & & \\
\hline W10 & $3 / 0 / 3 / 1$ & 212.6 & -62.1 & 217.3 & -63.9 & 27.9 & 20.5 \\
\hline W11 & $2 / 0 / 2 / 1$ & 165.5 & -33.4 & 165.6 & -36.4 & & \\
\hline W12 & $0 / 1 / 1 / 1$ & 173.8 & -34.6 & 174.3 & -37.5 & & \\
\hline W13 & $3 / 1 / 4 / 3$ & 165.3 & -36.1 & 165.4 & -39.1 & 9.5 & 95.0 \\
\hline W15 & $4 / 1 / 5 / 2$ & 193.1 & -30.1 & 194.1 & -32.7 & 12.4 & 39.3 \\
\hline W16 & $0 / 1 / 1 / 1$ & 203.5 & -44.0 & 205.5 & -46.2 & & \\
\hline W17 & $3 / 0 / 3 / 1$ & 203.1 & -29.6 & 204.3 & -31.8 & 25.2 & 25.0 \\
\hline W19 & $3 / 0 / 3 / 1$ & 208.4 & -26.3 & 209.5 & -28.3 & 12.0 & 106.5 \\
\hline W21 & $3 / 1 / 4 / 1$ & 202.5 & -34.4 & 203.9 & -36.7 & 11.9 & 61.0 \\
\hline W22 & $3 / 1 / 4 / 1$ & 193.1 & -36.1 & 194.3 & -38.7 & 10.4 & 78.9 \\
\hline W23 & $5 / 2 / 7 / 2$ & 199.3 & -32.0 & 200.5 & -34.4 & 5.1 & 143.3 \\
\hline W24 & $3 / 0 / 3 / 1$ & 194.9 & -48.6 & 196.9 & -51.1 & 34.1 & 14.1 \\
\hline W25 & $1 / 0 / 1 / 1$ & 190.9 & -38.8 & 192.1 & -41.4 & & \\
\hline W26 & $1 / 1 / 2 / 1$ & 210.7 & -43.9 & 213.0 & -45.8 & & \\
\hline W31 & 0/1/1/1 & 189.0 & -31.6 & 189.9 & -34.3 & & \\
\hline W32 & $5 / 2 / 7 / 2$ & 208.8 & -47.7 & 211.3 & -49.7 & 24.3 & 7.1 \\
\hline W33 & $3 / 1 / 4 / 1$ & 190.4 & -29.8 & 191.3 & -32.4 & 18.1 & 26.7 \\
\hline W34 & $2 / 0 / 2 / 1$ & 204.0 & -45.5 & 206.2 & -47.7 & & \\
\hline W36 & $3 / 1 / 4 / 1$ & 172.5 & -32.8 & 172.9 & -35.7 & 19.8 & 22.5 \\
\hline W37 & $3 / 1 / 4 / 1$ & 195.0 & -30.1 & 196.0 & -32.6 & 12.3 & 56.4 \\
\hline W38 & $1 / 0 / 1 / 1$ & 184.7 & -43.6 & 185.9 & -46.4 & & \\
\hline W39 & $4 / 2 / 6 / 2$ & 185.2 & -52.4 & 186.9 & -55.1 & 6.4 & 111.4 \\
\hline W40 & 0/1/1/1 & 209.9 & -35.3 & 211.6 & -37.3 & & \\
\hline W41 & $2 / 1 / 3 / 1$ & 184.8 & -35.3 & 185.7 & -38.1 & 26.7 & 22.4 \\
\hline W42 & $3 / 1 / 4 / 1$ & 199.0 & -37.8 & 200.5 & -40.2 & 16.2 & 33.0 \\
\hline W43 & $4 / 2 / 6 / 2$ & 204.1 & -44.7 & 206.2 & -46.9 & 10.9 & 38.9 \\
\hline E3 & $0 / 1 / 1 / 1$ & 187.3 & -18.3 & 187.8 & -21.0 & & \\
\hline E7 & $0 / 1 / 1 / 1$ & 191.2 & -57.9 & 193.8 & -60.5 & & \\
\hline E8 & $2 / 1 / 3 / 1$ & 178.7 & -37.3 & 179.4 & -40.2 & 26.7 & 22.4 \\
\hline E9 & $0 / 3 / 3 / 1$ & 174.0 & -40.7 & 174.6 & -43.6 & 11.3 & 121.0 \\
\hline E10 & $3 / 1 / 4 / 1$ & 201.4 & -59.4 & 204.9 & -61.7 & 11.8 & 61.1 \\
\hline E11 & $3 / 0 / 3 / 1$ & 155.4 & -43.4 & 155.0 & -46.4 & 7.1 & 298.7 \\
\hline E12 & $3 / 1 / 4 / 2$ & 170.9 & -37.7 & 171.3 & -40.7 & 6.6 & 196.6 \\
\hline E13 & $0 / 3 / 3 / 1$ & 178.3 & -41.8 & 179.1 & -44.7 & 21.5 & 34.0 \\
\hline E14 & $0 / 2 / 2 / 1$ & 175.0 & -23.7 & 175.3 & -26.6 & & \\
\hline E15 & $2 / 0 / 2 / 1$ & 188.0 & -29.3 & 188.8 & -32.0 & & \\
\hline E16 & $2 / 1 / 3 / 1$ & 187.9 & -19.8 & 188.4 & -22.5 & 10.1 & 151.3 \\
\hline E18 & $1 / 1 / 2 / 1$ & 191.4 & -46.7 & 193.1 & -49.3 & & \\
\hline
\end{tabular}

Table 1 Directions of reverse polarity ChRM components (Continued)

\begin{tabular}{llllllll}
\hline E19 & $0 / 2 / 2 / 1$ & 199.0 & -32.9 & 200.2 & -35.3 & & \\
E20 & $0 / 3 / 3 / 1$ & 202.1 & -30.3 & 203.3 & -32.6 & 5.9 & 431.0 \\
E22 & $3 / 1 / 4 / 1$ & 199.7 & -24.6 & 200.6 & -27.0 & 10.5 & 77.6 \\
E23 & $1 / 2 / 3 / 1$ & 208.1 & -21.2 & 209.0 & -23.3 & 31.3 & 16.5 \\
E26 & $0 / 1 / 1 / 1$ & 187.8 & -33.0 & 188.7 & -35.7 & & \\
Mean 1 & $92 / 50 / 142 / 56$ & 192.7 & -38.3 & 193.9 & -40.9 & 3.0 & 17.1 \\
Mean 2 & $(17)$ & 191.0 & -36.4 & 192.2 & -39.0 & 7.1 & 26.3 \\
\hline
\end{tabular}

naf and $n$th number of samples subjected to alternating field demagnetization and thermal demagnetization, respectively, $n$ total number of samples, $N$ number of oriented cores, $D i$ and $l i$ in situ declination and inclination, respectively, $D c$ and $/ c$ tilt-corrected declination and inclination, respectively, a95 radius of $95 \%$ confidence cone, $k$ precision parameter. Mean 1 overall mean of all sample ChRM directions ( $n=142)$. Mean 2 overall mean of site-mean directions ( 17 sites) with $n>2$ and $a_{95}<16.0^{\circ}$

consistent with the depositional age of the Oidawara Formation of 15.8-15.7 Ma, as based on diatom biostratigraphy (as noted above). Thus, deposition of the Oidawara Formation occurred during reverse polarity Chron C5Br (Fig. 2). As noted above, the demagnetization results for the fine tuff suggest that the reverse ChRM directions provide a record of the paleofield at or immediately after deposition, and the same is presumably true for the reverse ChRM directions of the siltstone samples.

Approximately $20 \%(n=35)$ of the sample ChRM directions for siltstone show normal polarity (red circles, Fig. 8a), typically showing northerly declinations and moderate $\left(\sim 55^{\circ}\right)$ inclinations. The in situ mean direction (declination, $D,=352.0^{\circ}$; inclination, $I,=55.4^{\circ} ; 95 \%$ confidence limit, $\alpha_{95},=4.1^{\circ}$ ) is close to the geocentric axial dipole field direction $\left(D=0^{\circ}, I=54.9^{\circ}\right.$; blue cross, Fig. 8a) and also the present-day geomagnetic field direction calculated from the 12th International Geomagnetic Reference Field model (IGRF-12; $D=352.5^{\circ}, I=49.6^{\circ}$; Thébault et al. 2015; green cross, Fig. 8a) at the representative latitude and longitude of the Shuku locality $\left(35.408^{\circ} \mathrm{N}, 137.258^{\circ} \mathrm{E}\right)$. Some of the normal ChRM directions probably represent secondary magnetization; for example, both normal and reverse ChRM directions coexist at site W6 (Fig. 4), and in this case, the normal directions are interpreted to represent secondary magnetization. However, it should be noted that the stratigraphically confined $\sim 5$-m-thick interval between 63 and $68 \mathrm{~m}$ above the base of the formation is clearly dominated by normal directions (Fig. 4). The lithologies of this normal polarity interval and the reverse polarity beds immediately above and below it are not notably different. Moreover, no notable differences in rock magnetic characteristics were detected between the normal polarity samples of this interval and the reverse polarity samples, as can be seen in both the ThD results of the three-axis IRM 


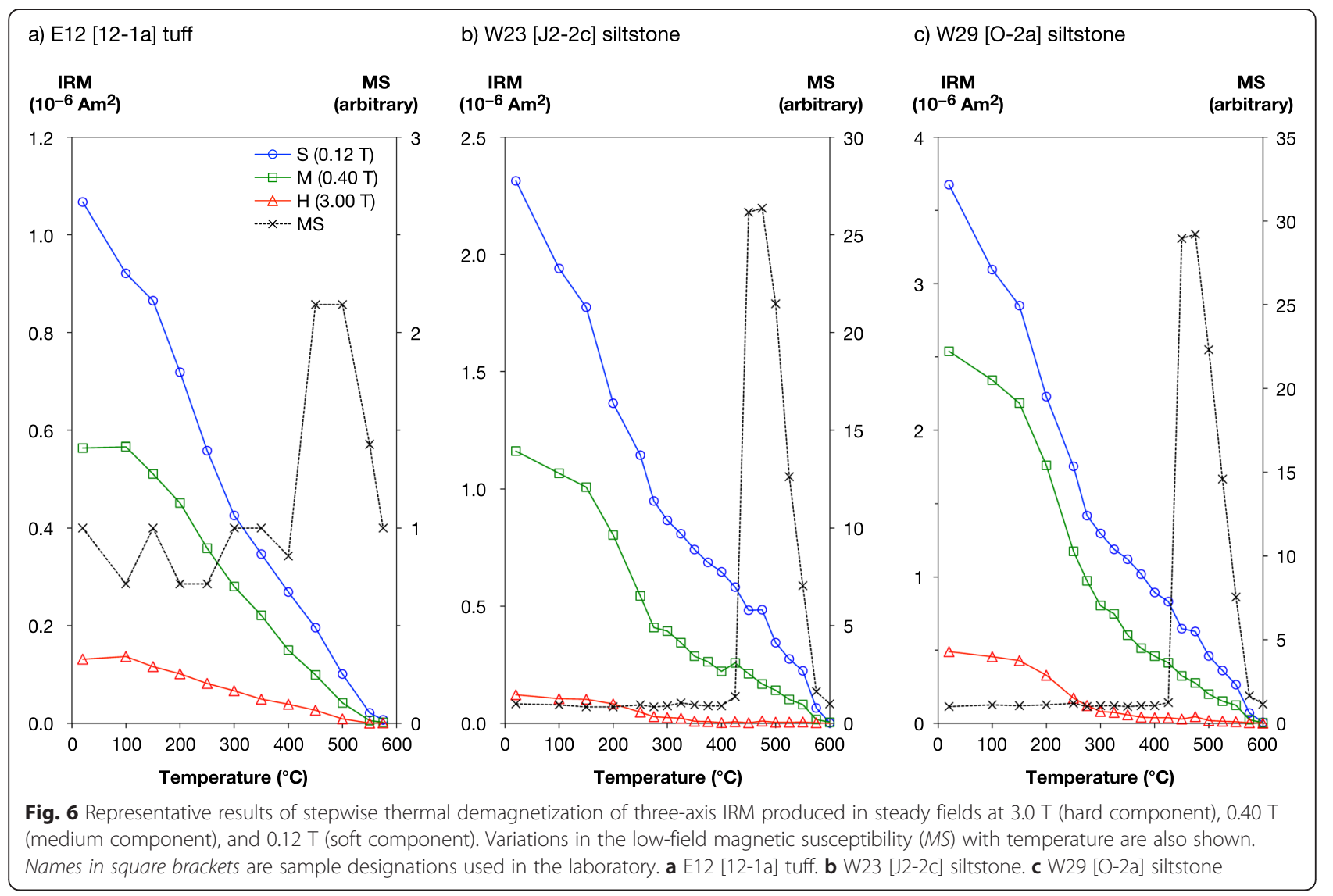

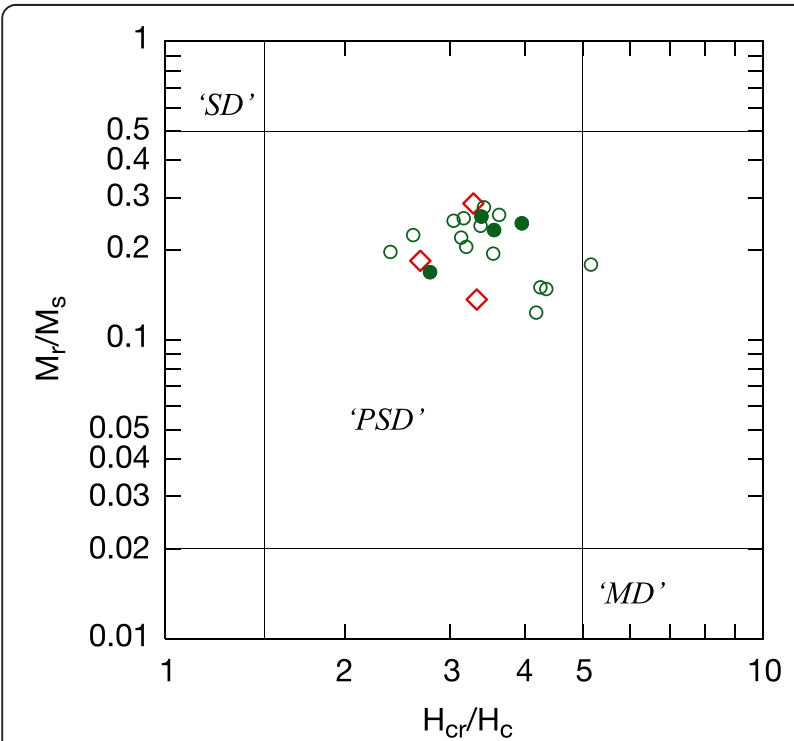

Fig. 7 Log-log plot of hysteresis data for fine felsic tuffs (red diamonds), siltstones having normal ChRM directions (green solid circles), and siltstones having reverse ChRM directions (green open circles).

single-domain (SD), pseudo-single-domain (PSD), and multidomain (MD) boundaries follow Dunlop (2002). $H_{c}$ coercive force, $H_{c r}$ coercivity of remanent magnetization, $M_{r}$ saturation remanent magnetization, $M_{s}$ saturation magnetization
Table 2 Directions of normal polarity ChRM components

\begin{tabular}{llllllll}
\hline Site & $n_{a f} / n_{t h} / n / N$ & $D_{i}$ & $l_{i}$ & $D_{c}$ & $l_{c}$ & $a_{95}$ & $k$ \\
& & $\left({ }^{\circ}\right)$ & $\left({ }^{\circ}\right)$ & $\left({ }^{\circ}\right)$ & $\left(^{\circ}\right)$ & $\left({ }^{\circ}\right)$ & \\
\hline W6 & $2 / 0 / 2 / 1$ & 4.6 & 40.7 & 5.7 & 43.5 & & \\
W27 & $3 / 0 / 3 / 1$ & 342.4 & 49.6 & 342.4 & 52.6 & 17.4 & 51.5 \\
W28 & $2 / 1 / 3 / 1$ & 7.1 & 58.4 & 9.3 & 61.1 & 25.5 & 24.4 \\
W29 & $9 / 3 / 12 / 3$ & 352.3 & 53.7 & 353.1 & 56.7 & 4.0 & 120.4 \\
W30 & $6 / 0 / 6 / 3$ & 348.2 & 56.0 & 348.8 & 59.0 & 11.2 & 36.9 \\
E1 & $1 / 0 / 1 / 1$ & 358.3 & 34.7 & 358.9 & 37.6 & & \\
E2 & $1 / 0 / 1 / 1$ & 12.2 & 65.5 & 15.9 & 68.0 & & \\
E4 & $2 / 0 / 2 / 1$ & 5.4 & 68.5 & 8.8 & 71.2 & & \\
E5 & $1 / 0 / 1 / 1$ & 331.7 & 53.3 & 330.9 & 56.2 & & \\
E21 & $1 / 0 / 1 / 1$ & 334.1 & 56.0 & 333.4 & 59.0 & & \\
E25 & $2 / 0 / 2 / 1$ & 321.6 & 75.4 & 316.6 & 78.1 & & \\
E28 & $1 / 0 / 1 / 1$ & 351.4 & 43.4 & 351.9 & 46.4 & & \\
Mean 1 & $31 / 4 / 35 / 16$ & 352.0 & 55.4 & 352.8 & 58.4 & 4.1 & 35.5 \\
Mean 2 & $(2)$ & 350.3 & 54.9 & 351.0 & 57.8 & & \\
\hline
\end{tabular}

See Table 1 for explanation 


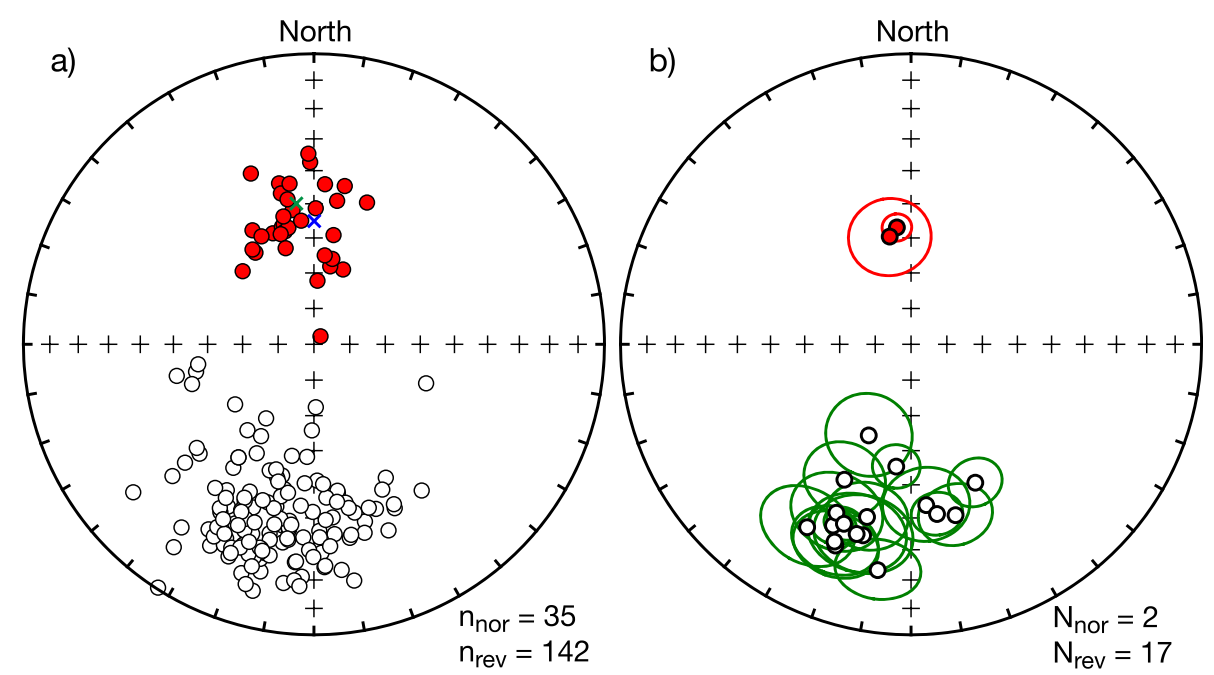

Fig. 8 Equal-area projections of paleomagnetic results. a Sample ChRM directions in geographic (in situ) coordinates. Red (open) circles denote directions in the lower (upper) hemisphere. The blue cross is the geocentric axial dipole field direction $\left(D=0^{\circ}, I=54.9^{\circ}\right)$; the green cross is the present-day geomagnetic field direction calculated from the 12th International Geomagnetic Reference Field model (IGRF-12; $\left.D=352.5^{\circ}, I=49.6^{\circ}\right)$. nnor (nrev) number of samples showing normal (reverse) polarity. b Site-mean directions for sites with number of samples $(n)>2$ and $a_{95}<16^{\circ}$ in stratigraphic (tilt-corrected) coordinates. The ovals around directions show the $95 \%$ confidence limits. Nnor (Nrev) number of sites showing normal (reverse) polarity

(Fig. 6b, c) and the hysteresis measurements (Fig. 7). Therefore, like the reverse polarity directions, we interpret the normal directions in this interval to represent a paleofield record acquired at or immediately after deposition. The duration of this interval must be very short geologically, probably on the order of $\sim 10 \mathrm{kyr}$ or shorter, based on very high sedimentation rates. We suggest that this interval was deposited during an unknown short normal polarity period (microchron or cryptochron) within Chron $\mathrm{C} 5 \mathrm{Br}$.

\section{Paleomagnetic directions and tectonic implications}

We obtained a tilt-corrected formation-mean direction for the Oidawara Formation of $D=10.5^{\circ}, I=41.1^{\circ}, \alpha_{95}=$ $7.0^{\circ}$, and $k$ (precision parameter) $=23.9$ by averaging 19 (2 normal and 17 reverse) site-mean directions satisfying the condition $n>2$ (where $n$ is the number of samples) and $\alpha_{95}<16^{\circ}$ (Fig. 8b). The two normal site-mean directions are from the short normal polarity interval described above. The formation-mean direction can be regarded as a reliable average of the paleosecular variation, as the 19 site-mean directions are distributed over a long stratigraphic interval $(\sim 60 \mathrm{~m})$ of fine-grained sediments containing three polarity intervals (reverse-normal-reverse). The mean inclination is shallower than the geocentric axial dipole field inclination, but this is clearly not due to large-scale $(>1000-\mathrm{km})$ northward translation, as such a shallow inclination has not been found in the underlying Akeyo Formation (see later) or in most other early to middle Miocene formations of Southwest Japan. The shallow inclination is probably the result of inclination shallowing (inclination error) caused by syn- and/or post-depositional processes (e.g., Tauxe 2005).

The mean declination $\left(D=10.5^{\circ}\right)$ is deflected slightly eastward and the $95 \%$ confidence limit on the declination $(\Delta D)$ is $9.3^{\circ}$ (based on the derivation of Demarest 1983). The eastward deflection is less than that of the mean declination of $D=25.8^{\circ}(n=2$ sites $)$ reported by Hayashida (1986).

We compared the formation-mean directions of the Oidawara and Akeyo formations. A total of 27 site-mean directions have been reported for the Akeyo Formation: 4 by Hayashida (1986), 20 by Hiroki and Matsumoto (1999), and 3 by Itoh et al. (2006). Of these, 19 show $\alpha_{95}$ values of less than $16^{\circ}$, yielding a more eastwarddeflected formation-mean direction of $D=49.9^{\circ}(\Delta D=$ $\left.9.5^{\circ}\right), I=51.9^{\circ}, \alpha_{95}=5.8^{\circ}$. The difference between the declinations of the two formation-mean directions is $39.4^{\circ} \pm 10.6^{\circ}$, indicating $\sim 40^{\circ}$ of clockwise rotation in the Mizunami area between deposition of the Akeyo Formation (18.1-17.5 Ma; Chron C5Dr) and deposition of the Oidawara Formation (15.8-15.7 Ma).

Figure 9 shows a rotation versus age plot (data are listed in Table 3). The amount of rotation for each geological formation or locality was calculated using the direction-space approach (Butler 1992), in which observed directions are compared with expected directions derived from the position of the early to middle Miocene paleomagnetic pole for Shandong Province (Fig. 1) in the North China Block (NCB; Zhao et al. 1994). Figure 9 includes data not only for the Mizunami area (Akeyo and Oidawara formations) but also for the Hachiya 


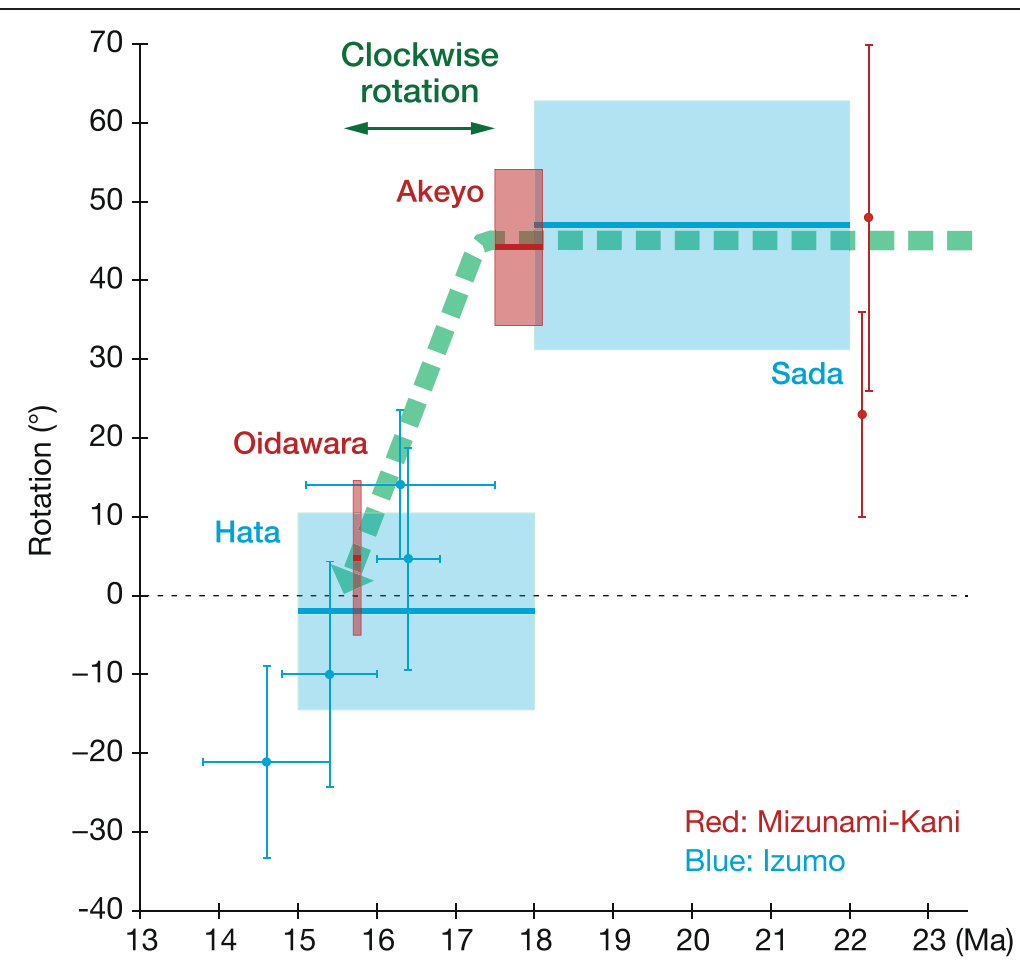

Fig. 9 Plot of rotation versus age data for lithological units of the Mizunami-Kani and Izumo areas (see Table 3 for data). Rotations are defined as positive if the observed declination is clockwise with respect to the expected declination calculated from the reference North China Block data

Formation in the Kani area (Hayashida et al. 1991), located adjacent to Mizunami. Note that the data for the Hachiya Formation (two red circles with error bars, Fig. 9) are site means of volcanic rocks and therefore may be strongly influenced by the paleosecular variation.
The diagram also contains formation-mean and sitemean data from the Izumo area in central Southwest Japan, recently reported by Sawada et al. (2013). Otofuji and colleagues obtained a wealth of paleomagnetic and radiometric results from in and around the Izumo area

Table 3 Summary of the early to middle Miocene paleomagnetic directions of the Mizunami-Kani and Izumo areas

\begin{tabular}{|c|c|c|c|c|c|c|c|c|}
\hline & Age & $N$ & $D$ & 1 & $a_{95}$ & $R$ & $\Delta R$ & Ref. \\
\hline & (Ma) & & $\left({ }^{\circ}\right)$ & $\left({ }^{\circ}\right)$ & $\left({ }^{\circ}\right)$ & $\left({ }^{\circ}\right)$ & $\left({ }^{\circ}\right)$ & \\
\hline \multicolumn{9}{|l|}{ Mizunami-Kani } \\
\hline Oidawara F & $15.8-15.7$ & 19 & 10.5 & 41.1 & 7.0 & 4.8 & 9.8 & 1 \\
\hline Akeyo F & $18.1-17.5$ & 19 & 49.9 & 51.9 & 5.8 & 44.2 & 9.9 & $2,3,4$ \\
\hline Hachiya F (site HCY5)* & 22.2 & (6) & 28.7 & 57.6 & 7.5 & 23.0 & 13.0 & 5 \\
\hline Hachiya F (site HCY4)* & 22.2 & $(6)$ & 53.8 & 60.5 & 12.5 & 48.1 & 21.8 & 5 \\
\hline \multicolumn{9}{|l|}{ Izumo } \\
\hline Omori F (site 08120205)* & $14.6 \pm 0.8$ & (4) & 344.4 & 49.4 & 8.5 & -22.1 & 12.2 & 6 \\
\hline Kawai F (site 08122002)* & $15.4 \pm 0.6$ & (3) & 355.5 & 43.4 & 11.6 & -10.0 & 14.3 & 6 \\
\hline Hata F & $18-15$ & 6 & 3.5 & 42.9 & 9.9 & -2.0 & 12.5 & 6 \\
\hline Daito F (site DT-1)* & $16.3 \pm 1.2$ & (5) & 19.6 & 32.6 & 7.5 & 14.1 & 9.5 & 6 \\
\hline Yoshida PC (site YS-1)* & $16.4 \pm 0.4$ & (4) & 10.2 & 53.4 & 9.3 & 4.7 & 14.1 & 6 \\
\hline Sada F & $22-18$ & 6 & 52.5 & 43.2 & 13.1 & 47.0 & 15.8 & 6 \\
\hline
\end{tabular}

Data with asterisks are site-mean directions of igneous rocks

$N$ number of sites (number of samples in parentheses), $D$ declination, $I$ inclination, $a 95$ radius of $95 \%$ confidence cone, $R$ angle of rotation with respect to the North China Block (positive for an observed direction clockwise from the expected direction), $\Delta R 95 \%$ confidence limit of $R$, calculated after Demarest (1983), F formation, PC plutonic complex. References: 1 this study, 2 Hayashida (1986), 3 Hiroki and Matsumoto (1999), 4 Itoh et al. (2006), 5 Hayashida et al. (1991),

6 Sawada et al. (2013) 
(Otofuji and Matsuda 1983, 1984, 1987; Otofuji et al. 1991), and these results played an important role in the development of the 15-Ma rapid rotation model (these studies are reviewed by Otofuji 1996). However, Jolivet et al. (1995) and Sawada et al. (2013) have pointed out that the lithostratigraphy and chronostratigraphy of the volcanic succession investigated by Otofuji and colleagues remains unclear. Sawada et al. (2013) revisited the succession and proposed a new stratigraphic architecture. They also obtained paleomagnetic results from radiometrically dated volcanic and plutonic rocks.

The rotation versus age plot in Fig. 9 indicates similar temporal changes for the rotations of the MizunamiKani and Izumo areas, suggesting that similar amounts of clockwise rotation occurred in both areas during the same time interval. The amount of rotation of the Akeyo Formation $\left(44.2^{\circ} \pm 9.9^{\circ}\right)$ is identical to that of the Sada Formation in Izumo $\left(47.0^{\circ} \pm 15.8^{\circ}\right)$. These values are compatible with an approximate estimate for the amount of clockwise rotation of Southwest Japan $\left(\sim 45^{\circ}\right.$; Otofuji and Matsuda 1987). Determination of the amount of rotation of an entire arc is not easy if, as claimed by Jolivet et al. (1995), the arc has fragmented into several pieces during the rotation, and if each piece exhibits an indeterminate amount of intra-arc block rotation. However, results from Late Cretaceous rocks of eastern Southwest Japan suggest that intra-arc block rotation, if any, has been negligible (Fukuma et al. 2003). Therefore, it is likely that the temporal changes in the rotations of Miocene rocks are the result of clockwise rotation involving the entirety of Southwest Japan. We suggest that the clockwise rotation occurred after the deposition of the Akeyo Formation (i.e., after 17.5 Ma). The near-identical rotation of the Mizunami-Kani and Izumo areas also suggests that lateral bending of the crust in central Honshu, caused by collision of the Izu-Bonin arc with the eastern margin of Southwest Japan (e.g., Takahashi and Saito 1997), does not extend to the Mizunami area. This has also been ascertained by a comparison of paleomagnetic directions for Mizunami with those for other areas in eastern Southwest Japan (Itoh et al. 2006).

The amount of rotation of the Oidawara Formation $\left(4.8^{\circ} \pm 9.8^{\circ}\right)$ indicates virtually no clockwise rotation with respect to the NCB. This result is compatible with data from $~ 16-\mathrm{Ma}$ volcanic rocks from the Izumo area. Our interpretation is that the clockwise rotation of Southwest Japan had largely ceased before the onset of deposition of the Oidawara Formation (15.8 Ma). The rotation rate is thus estimated at $\sim 23^{\circ} / \mathrm{Myr}$, based on a change in direction from $44.2^{\circ}$ at $17.5 \mathrm{Ma}$ to $4.8^{\circ}$ at $15.8 \mathrm{Ma}$. The data from Izumo also suggest that clockwise rotation was complete by $15 \mathrm{Ma}$. Furthermore, studies conducted in other areas of Southwest Japan have provided timeaveraged mean directions suggesting little or no rotation since 15 Ma (Nakajima et al. 1990; Itoh et al. 2000; Hoshi et al. 2000b; Hoshi and Yokoyama 2001; Tamaki et al. 2006; Hoshi and Sano 2013).

One of the key observations that led to the development of the 15-Ma rapid rotation model was the occurrence of eastward-deflected paleomagnetic directions of Miocene rocks on the forearc side of Southwest Japan. In the review by Otofuji et al. (1985a), some of the Miocene sedimentary formations showing an eastward-deflected direction were estimated to be of middle Miocene age (16-15 Ma). However, recent radiometric, biostratigraphic, and magnetostratigraphic studies indicate that the actual age is $18-17 \mathrm{Ma}$ (Ito et al. 1999; Watanabe et al. 1999; Hoshi et al. 2000a, 2006; Hoshi and Saida 2009; Sako and Hoshi 2014). In addition, Hoshi (2002) and Hoshi et al. (2013) raised the possibility that the eastward-deflected direction of middle Miocene volcanic rocks dated at 15-14 Ma records an extraordinary paleofield, such as may have occurred during a geomagnetic excursion or polarity transition and does not therefore represent a time-averaged direction. Shimada et al. (2001) presented paleomagnetic and K-Ar data that appear consistent with the 15-Ma rapid rotation model, but the data are site-mean directions of volcanic rocks and are therefore influenced to a large degree by the paleosecular variation. In summary, most of the welldated, time-averaged paleomagnetic directions obtained for Southwest Japan are inconsistent with the 15-Ma rapid rotation model.

\section{Conclusions}

Magnetic measurements conducted on sedimentary rocks from the Oidawara Formation, Mizunami Group, yielded paleomagnetic data that constrain the timing of the clockwise rotation of Southwest Japan. Reverse polarity directions are recorded by $\sim 80 \%$ of the ChRM directions obtained in this study and are thought to represent primary magnetization. Normal polarity ChRM directions represent primary paleofield records and secondary magnetization and suggest the presence of a shortduration normal polarity interval (microchron or cryptochron) within Chron C5Br. The Oidawara Formation records a paleomagnetic direction that indicates virtually no rotation with respect to the NCB. Clockwise rotation of Southwest Japan occurred mainly between 17.5 and $15.8 \mathrm{Ma}$, at a rotation rate of $\sim 23^{\circ} / \mathrm{Myr}$.

\section{Competing interests}

The authors declare that they have no competing interests.

\section{Authors' contributions}

$\mathrm{HH}$ designed the project and drafted the manuscript. $\mathrm{HH}$, DK, and YA mapped geologic structures, identified sedimentary lithologies, collected rock samples at the Shuku locality, and performed the magnetic experiments. KN conducted the mineralogical observations. All authors read and approved the final manuscript. 


\section{Acknowledgements}

We thank Itsuki Suto and Yusuke Ando for providing information on the field geology of the Shuku locality. Discussions in the field with Yukio Yanagisawa are greatly appreciated. This study was performed under the cooperative research program of the Center for Advanced Marine Core Research of Kochi University (12A004, 12B003, 13A003, 13B003, 14A014, 14B012), and we thank Yuhji Yamamoto and Kazuto Kodama for their assistance during the program. We are grateful for constructive reviews by two anonymous referees and for comments by the editor, Hirokuni Oda. This study was supported by Grants-in-Aid for Scientific Research from the Japan Society for the Promotion of Science $(23540532,26400488)$.

\section{Author details}

'Department of Earth Sciences, Aichi University of Education, Kariya, Aichi 448-8542, Japan. ${ }^{2}$ Department of Earth and Environmental Sciences, Yamagata University, Yamagata 990-8560, Japan.

Received: 13 February 2015 Accepted: 8 June 2015

Published online: 19 June 2015

\section{References}

Arai R, Iwasaki T (2014) Crustal structure in the northwestern part of the Izu collision zone in central Japan. Earth Planets Space 66(1):1-12. doi:10.1186/ 1880-5981-66-21

Butler RF (1992) Paleomagnetism: magnetic domains to geologic terranes. Blackwell, Boston

Cho I, Kuwahara Y (2013) Numerical simulation of crustal deformation using a three-dimensional viscoelastic crustal structure model for the Japanese islands under east-west compression. Earth Planets Space 65(9):1041-6. doi:10.5047/eps.2013.05.006

Demarest HH Jr (1983) Error analysis for the determination of tectonic rotation from paleomagnetic data. J Geophys Res 88(B5):4321-8. doi:10.1029/ JB088iB05p04321

Dunlop DJ (2002) Theory and application of the Day plot $\left(M_{r s} / M_{s}\right.$ versus $\left.H_{C I} / H_{C}\right) 1$. Theoretical curves and tests using titanomagnetite data. J Geophys Res: Solid Earth 107(B3):EPM 4-1-EPM 4-22. doi:10.1029/2001jb000486

Fukuma K, Tsurudome H, Torii M (2003) A Late Cretaceous paleomagnetic pole from Koto rhyolite, southwest Japan: implications for eastern margin deformation of Asia. J Geophys Res 108(B11):2544. doi:10.1029/2001jb000425

Gladenkov AY (1998) Oligocene and lower Miocene diatom zonation in the North Pacific. Stratigr Geol Correl 6(2):150-63

Hayashida A (1986) Timing of rotational motion of Southwest Japan inferred from paleomagnetism of the Setouchi Miocene Series. J Geomagn Geoelectr 38(5):295-310. doi:10.5636/jgg.38.295

Hayashida A, Fukui T, Torii M (1991) Paleomagnetism of the Early Miocene Kani Group in southwest Japan and its implication for the opening of the Japan Sea. Geophys Res Lett 18(6):1095-8. doi:10.1029/91GL01349

Hiroki Y, Matsumoto R (1999) Magnetostratigraphic correlation of Miocene regression-and-transgression boundaries in central Honshu, Japan. J Geol Soc Jpn 105(2):87-107. doi:10.5575/geosoc.105.87

Hoshi H (2002) Paleomagnetic direction of the Kumano Acidic lgneous Rocks, Kii peninsula, Japan. Bull Geol Surv Jpn 53(1):43-50. doi:10.9795/bullgsj.53.43 [in Japanese with English abstract]

Hoshi H, Saida T (2009) Magnetostratigraphy of the Lower Miocene Hokusetsu Subgroup in the Shitara district, Aichi Prefecture, central Japan. J Geol Soc Jpn 115(5):193-205. doi:10.5575/geosoc.115.193 [in Japanese with English abstract]

Hoshi H, Sano M (2013) Paleomagnetic constraints on Miocene rotation in the central Japan Arc. Isl Arc 22(2):197-213. doi:10.1111/iar.12022

Hoshi H, Takahashi M (1999) Miocene counterclockwise rotation of Northeast Japan: a review and new model. Bull Geol Surv Jpn 50(1):3-16

Hoshi H, Yokoyama M (2001) Paleomagnetism of Miocene dikes in the Shitara basin and the tectonic evolution of central Honshu, Japan. Earth Planets Space 53(7):731-9. doi:10.1186/bf03352401

Hoshi H, Ito N, Motoyama I (2000a) Geology, radiolarians, and geologic age of the Hokusetsu Subgroup in the Shitara area, Aichi Prefecture, central Japan J Geol Soc Jpn 106(10):713-26. doi:10.5575/geosoc.106.713 [in Japanese with English abstract]

Hoshi H, Tanaka D, Takahashi M, Yoshikawa T (2000b) Paleomagnetism of the Nijo Group and its implication for the timing of clockwise rotation of southwest Japan. J Mineral Petrol Sci 95(8):203-15. doi:10.2465/jmps.95.203
Hoshi H, Danhara T, Iwano H (2006) New age constraints on the Miocene tectonic evolution of southwestern Japan: fission track ages from the Shitara district, Aichi Prefecture. J Geol Soc Jpn 112(2):153-65. doi:10.5575/ geosoc.112.153 [in Japanese with English abstract]

Hoshi H, Kamiya N, Kawakami Y (2013) Instantaneous paleomagnetic record from the Miocene Kozagawa Dike of the Kumano Acidic Rocks, Kii Peninsula, Southwest Japan: cautionary note on tectonic interpretation. Isl Arc 22(3):395-409. doi:10.1111/iar.12027

Ito C, Irizuki T, Iwai M (1999) Diatom zonal key species and geologic ages of the Miocene Morozaki, Iwamura and Tomikusa Groups in the First Setouchi Province, central Japan. J Geol Soc Jpn 105(2):152-5. doi:10.5575/ geosoc.105.152 [in Japanese with English abstract]

Itoh Y, Yamamoto A, Iwano H, Danhara T, Watanabe M (2000) Paleomagnetism and fission-track ages of the Miocene sequence in the Kanazawa and lozen areas, central Japan. Bull Geol Surv Jpn 51(10):495-504 [in Japanese with English abstract]

Itoh Y, Amano K, Kumazaki N (2006) Integrated description of deformation modes in a sedimentary basin: a case study around a shallow drilling site in the Mizunami area, eastern part of southwest Japan. Is Arc 15(1):165-77. doi:10.1111/j.1440-1738.2006.00506.x

Itoh Y, Kusumoto S, Takemura K (2014) Evolutionary process of Beppu Bay in central Kyushu, Japan: a quantitative study of the basin-forming process controlled by plate convergence modes. Earth Planets Space 66(1):1-14 doi:10.1186/1880-5981-66-74

Itoigawa J (1974) Geology of the Mizunami Group. Bull Mizunami Fossil Mus 1:9-42 [in Japanese]

Itoigawa J (1980) Geology of the Mizunami district, central Japan. Monogr Mizunami Fossil Mus 1:1-50 [in Japanese]

Jolivet L, Shibuya H, Fournier M (1995) Paleomagnetic rotations and the Japan Sea opening. In: Taylor B, Natland J (eds) Active margins and marginal basins of the western Pacific. AGU, p 355-69. doi:10.1029/GM088p0355

Kano K, Uto K, Ohguchi T (2007) Stratigraphic review of Eocene to Oligocene successions along the eastern Japan Sea: implication for early opening of the Japan Sea. J Asian Earth Sci 30(1):20-32. doi:10.1016/ j.jseaes.2006.07.003

Kawamura K, Suto I, Yanagisawa Y (2011) Diatom biostratigraphy of the middle Miocene Oidawara Formation in the Mizunami area, Gifu Prefecture, central Japan. Diatom 27:17-32. doi:10.11464/diatom.27.17 [in Japanese with English abstract]

Kirschvink JL (1980) The least-squares line and plane and the analysis of palaeomagnetic data. Geophys J Roy Astron Soc 62(3):699-718. doi:10.1111/j.1365-246X.1980.tb02601.X

Kobayashi T (1989) Geology and uranium mineralization in the eastern part of the Kani basin, Gifu, Central Japan. Mining Geol 39(214):79-94. doi:10.11456/shigenchishitsu1951.39.214_79 [in Japanese with English abstract]

Lowrie W (1990) Identification of ferromagnetic minerals in a rock by coercivity and unblocking temperature properties. Geophys Res Lett 17(2):159-62. doi:10.1029/GL017i002p00159

Lurcock PC, Wilson GS (2012) PuffinPlot: a versatile, user-friendly program for paleomagnetic analysis. Geochem Geophys Geosyst 13:Q06Z45. doi:10.1029/ 2012 gc004098

Martin AK (2011) Double saloon door tectonics in the Japan Sea, Fossa Magna, and the Japanese Island Arc. Tectonophysics 498(1-4):45-65. doi:10.1016/ j.tecto.2010.11.016

Nakajima T, Sawada Y, Nakagawa T, Hayashi A, Itaya T (1990) Paleomagnetic results and K-Ar dating on Miocene rocks in the northern part of Fukui Prefecture, central Japan: with reference to the rotation of Southwest Japan. J Mineral Petrol Econ Geol 85(2):45-59. doi:10.2465/ganko.85.45 [in Japanese with English abstract]

Ogg JG (2012) Chapter 5 - Geomagnetic polarity time scale. In: Gradstein FM, Ogg JG, Schmitz MD, Ogg GM (eds) The geologic time scale 2012. Elsevier, Boston, pp 85-113. doi:http://dx.doi.org/10.1016/B978-0-444-59425-9.00005-6

Otofuji Y-i (1996) Large tectonic movement of the Japan Arc in late Cenozoic times inferred from paleomagnetism: review and synthesis. Isl Arc 5(3):229-49. doi:10.1111/j.1440-1738.1996.tb00029.x

Otofuji Y-i, Matsuda T (1983) Paleomagnetic evidence for the clockwise rotation of Southwest Japan. Earth Planet Sci Lett 62(3):349-59. doi:10.1016/0012$821 \times(83) 90005-5$

Otofuji Y-i, Matsuda T (1984) Timing of rotational motion of Southwest Japan inferred from paleomagnetism. Earth Planet Sci Lett 70(2):373-82. doi:10.1016/0012-821x(84)90021-9 
Otofuji Y-i, Matsuda T (1987) Amount of clockwise rotation of Southwest Japan: fan shape opening of the southwestern part of the Japan Sea. Earth Planet Sci Lett 85(1-3):289-301. doi:10.1016/0012-821x(87)90039-2

Otofuji Y-i, Hayashida A, Torii M (1985a) When was the Japan Sea opened? paleomagnetic evidence from Southwest Japan. In: Nasu N, Uyeda S, Kobayashi K, Kushiro I, Kagami H (eds) Formation of active ocean margins. Terrapub, Tokyo, pp 551-66

Otofuji Y-i, Matsuda T, Nohda S (1985b) Opening mode of the Japan Sea inferred from the palaeomagnetism of the Japan Arc. Nature 317(6038):603-4. doi:10.1038/317603a0

Otofuji Y-i, Matsuda T, Nohda S (1985c) Paleomagnetic evidence for the Miocene counter-clockwise rotation of Northeast Japan: rifting process of the Japan arc. Earth Planet Sci Lett 75(2-3):265-77. doi:10.1016/0012-821x(85)90108-6

Otofuji Y-i, Itaya T, Matsuda T (1991) Rapid rotation of southwest Japanpalaeomagnetism and $\mathrm{K}$-Ar ages of Miocene volcanic rocks of southwest Japan. Geophys J Int 105(2):397-405. doi:10.1111/j.1365-246X.1991.tb06721.x

Otofuji Y-i, Kambara A, Matsuda T, Nohda S (1994) Counterclockwise rotation of Northeast Japan: paleomagnetic evidence for regional extent and timing of rotation. Earth Planet Sci Lett 121(3-4):503-18. doi:10.1016/0012-821x(94)90087-6

Sako K, Hoshi H (2014) Paleomagnetism and tectonic significance of the Miocene Tomikusa Group in central Honshu, Japan. J Geol Soc Jpn 120(8):255-71. doi:10.5575/geosoc.2014.0025 [in Japanese with English abstract]

Sasaki T, Yamazaki T, Ishizuka O (2014) A revised spreading model of the West Philippine Basin. Earth Planets Space 66(1):1-9. doi:10.1186/1880-5981-66-83

Sasao E (2013) Petrographic study of the Miocene Mizunami Group, Central Japan: detection of unrecognized volcanic activity in the Setouchi Province. Is| Arc 22(2):170-84. doi:10.1111/iar.12019

Sasao E, Iwano H, Danhara T (2006) Fission track ages of tuffaceous sandstone from the Toki Lignite-bearing Formation of the Mizunami Group in the Tono district, Gifu Prefecture, central Japan. J Geol Soc Jpn 112(7):459-68. doi:10.5575/geosoc.112.459 [in Japanese with English abstract]

Sasao E, Danhara T, Iwano H, Hayashi J (2011) Fission track ages of the Miocene Mizunami and Iwamura Groups in southeastern Gifu Prefecture, Central Japan. J Geol Soc Jpn 117(8):476-81. doi:10.5575/geosoc.117.476 [in Japanese with English abstract]

Sawada Y, Mishiro Y, Imaoka T, Yoshida K, Inada R, Hisai K et al (2013) K-Ar ages and paleomagnetism of the Miocene in the Izumo Basin, Shimane Prefecture. J Geol Soc Jpn 119(4):267-84. doi:10.5575/geosoc.2012.0044 [in Japanese with English abstract]

Shimada M, Sumii T, Torii M (2001) Paleomagnetic directions and K-Ar ages of Setouchi volcanic rocks in Takanawa peninsula: constraints for the timing of the clockwise rotation of Southwest Japan. J Geol Soc Jpn 107(12):773-783. doi:10.5575/geosoc.107.773 [in Japanese with English abstract]

Takahashi M, Saito K (1997) Miocene intra-arc bending at an arc-arc collision zone, central Japan. Isl Arc 6(2):168-82. doi:10.1111/j.14401738.1997.tb00168.x

Tamaki K, Suyehiro K, Allan J, Ingle JC Jr, Pisciotto KA (1992) Tectonic synthesis and implications of Japan Sea ODP drilling. In: Tamaki K, Suyehiro K, Allan J, McWilliams M et al. (eds) Proceedings of ODP Science Results 127/128 (Part 2): College Station, TX (Ocean Drilling Program), pp.1333-1348. doi:10.2973/ odp.proc.sr.127128-2.240.1992

Tamaki M, Itoh Y, Watanabe M (2006) Paleomagnetism of the Lower to Middle Miocene Series in the Yatsuo area, eastern part of southwest Japan: clockwise rotation and marine transgression during a short period. Bull Geol Surv Jpn 57(3-4):73-88

Tauxe $L$ (2005) Inclination flattening and the geocentric axial dipole hypothesis. Earth Planet Sci Lett 233(3-4):247-61. doi:10.1016/j.epsl.2005.01.027

Thébault E, Finlay CC, Beggan CD, Alken P, Aubert J, Barrois O et al (2015) International Geomagnetic Reference Field: the 12th generation. Earth Planets Space 67:79. doi:10.1186/s40623-015-0228-9

Torii M (1983) Paleomagnetism of Miocene rocks in the Setouchi province: evidence for rapid clockwise rotation of Southwest Japan at Middle Miocene time, Ph.D Thesis. Kyoto University, Kyoto

Ujihara A, Irizuki T, Hosoyama M (1999) Neogene of Tono district, Gifu Prefecture, central Japan. In: Suzuki K, Takeuchi M (eds) Excursion guidebook, 106th annual meeting of the Geological Society of Japan. Nagoya, Geol Soc Jpn, pp 97-116 [in Japanese]

Watanabe M, Yanagisawa Y (2005) Refined Early to Middle Miocene diatom biochronology for the middle- to high-latitude North Pacific. Isl Arc 14(2):91-101. doi:10.1111/j.1440-1738.2005.00460.x
Watanabe M, Miyake M, Nozaki S, Yamamoto Y, Takemura A, Nishimura T (1999) Miocene diatom fossils from the Bihoku Group in Koyamaichi area and the Katsuta Group in Tsuyama area, Okayama Prefecture, southwest Japan. J Geol Soc Jpn 105(2):116-21. doi:10.5575/geosoc.105.116 [in Japanese with English abstract]

Yanagisawa Y, Akiba F (1998) Refined Neogene diatom biostratigraphy for the northwest Pacific around Japan, with an introduction of code numbers for selected diatom biohorizons. J Geol Soc Jpn 104(6):395-414. doi:10.5575/ geosoc. 104.395

Yoon S (1997) Miocene-Pleistocene volcanism and tectonics in southern Korea and their relationship to the opening of the Japan Sea. Tectonophysics 281(1-2):53-70. doi:10.1016/S0040-1951(97)00158-3

Zhao X, Coe R, Zhou Y, Hu S, Wu H, Kuang G et al (1994) Tertiary paleomagnetism of North and South China and a reappraisal of late Mesozoic paleomagnetic data from Eurasia: implications for the Cenozoic tectonic history of Asia. Tectonophysics 235(1-2):181-203. doi:10.1016/0040-1951(94)90023-x

\section{Submit your manuscript to a SpringerOpen ${ }^{\odot}$ journal and benefit from:}

- Convenient online submission

- Rigorous peer review

- Immediate publication on acceptance

- Open access: articles freely available online

- High visibility within the field

- Retaining the copyright to your article

Submit your next manuscript at $>$ springeropen.com 